\title{
Homeopatia na fissura por cocaína-crack. estudo randomizado, duplo-cego e placebo controlado (Estudo COCACRACK)
}

\author{
Ubiratan Cardinalli Adler², Ilma Barreto Garcia Saraiva², Maria Flora de Almeida², Marta Jezierski", \\ Amarilys de Toledo Cesar ${ }^{5}$, Edson Zangiacomi Martinez ${ }^{6}$, José Carlos Fernandes Galduróz
}

\author{
1 Centro de Atenção Psicossocial (CAPS II), São Carlos, SP. \\ 2 Centro de Atendimento à Pessoa Deficiente (CAPD), Guarulhos, SP. \\ ${ }^{3}$ Centro de Referência de Álcool, Tabaco e Outras Drogas (CRATOD), São Paulo, SP. \\ ${ }^{4}$ Centro Brasileiro de Informações sobre Drogas (CEBRID), São Paulo, SP. \\ 5 Farmácia Homeopática HN-Cristiano, São Paulo, SP. \\ ${ }_{6}^{6}$ Faculdade de Medicina de Ribeirão Preto, Universidade de São Paulo (FMRP/USP), Ribeirão Preto, SP. \\ 7 Universidade Federal de São Paulo (Unifesp), São Paulo, SP.
}

Received: 10/1/2013 - Accepted: 10/10/2013

Adler UC, et al. / Rev Psiq Clín. 2013;40(6):241-2

\section{Dear Editor}

Current therapeutical options for cocaine craving are still limited, favoring the seek for solutions in Complementary and Alternative Medicine (CAM). Homeopathy is a CAM modality recognized as a medical specialty in Brazil. Homeopathic medicines are produced through sequentially agitated dilutions in decimal (D), centesimal (C) or fifty-millesimal (Quinquagintamillesimal, Q or LM) potencies ${ }^{1}$. The efficacy or effectiveness of homeopathic remedies for cocaine dependency has not yet been investigated. We conducted an exploratory randomized, placebo controlled, double-blind 4-week clinical trial aiming at assessing the efficacy and tolerability of the homeopathic medicines Opium and Erythroxylum coca in the complementary treatment of cocaine craving. The study was carried out in São Paulo, in the so called "cracolândia" area, at the Centro de Referência de Álcool, Tabaco e Outras Drogas (CRATOD), with the approval of the Ethics Committee of Universidade Federal de São Paulo (Unifesp). Trial Registration: RBR-67zvt5 (Brazilian Clinical Trials Registry). Patients: Between January and November 2012, 42 patients with a diagnosis of cocaine dependency according to DSM-IV TR criteria were included. The study was interrupted due to low adherence. The majority of participants were unemployed (88\%), living in shelters or on the streets of São Paulo downtown area. Interventions: In the homeopathy group patients were treated at CRATOD with conventional treatment and Opium 2 LM, 1 daily sucrose globule melted on the tongue, during the first two weeks, and Erythroxylum coca 2 LM, same dosage, in the following two weeks. Comparison: In the placebo group patients received conventional treatment and 1 sucrose globule a day for the four weeks. During the period of the study, conventional treatment at CRATOD included therapeutic and income generation workshops; motivational groups; group and individual psychotherapies; medical treatment of substance dependency and of clinical/psychiatric comorbidities. Results: Out of the 42 included patients, only $23(54.8 \%)$ returned at least once and were considered for statistical analysis. Twelve patients (52\%) were randomized to group 1 (homeopathy) and 11 (48\%) to group 2 (placebo). No significant between-group differences were found regarding efficacy (Minnesota Cocaine Craving Scale ${ }^{2}$ ) or side effects (Scandinavian Society of Psychopharmacology Side Effect Rating $\left.\mathrm{Scale}^{3}\right)$. Within the homeopathy group, analysis suggests a reduction in the frequency of longer craving episodes and an increased sensation that the medicine contributed to the reduction of craving (final results compared to baseline - Table 1). Larger samples of patients with higher adherence are necessary to evaluate these differences, not observed in the placebo group.

Table 1. Percentage of patients reporting craving episodes $>20$ minutes and the sensation that the medicine has contributed to the reduction of craving

\begin{tabular}{|c|c|c|c|c|c|}
\hline \multicolumn{6}{|c|}{$\%$ reporting craving episodes $>20$ minutes } \\
\hline Groups & Week 0 & Week 1 & Week 2 & Week 3 & Week 4 \\
\hline $\begin{array}{l}\text { Homeopathy - mean } \\
(95 \% \mathrm{Cl})\end{array}$ & $\begin{array}{c}79.8 \\
(64.3 ; 92.9)\end{array}$ & $\begin{array}{c}16.3 \\
(3.4 ; 33.0)^{*}\end{array}$ & $\begin{array}{c}35.1 \\
(16.3 ; 59.3)^{*}\end{array}$ & $\begin{array}{c}37.2 \\
(11.4 ; 65.6)^{*}\end{array}$ & $\begin{array}{c}35.6 \\
(12.0 ; 58.7)^{*}\end{array}$ \\
\hline $\begin{array}{l}\text { Placebo - mean } \\
(95 \% \mathrm{CI})\end{array}$ & $\begin{array}{c}53.6 \\
(37.6 ; 70.3)\end{array}$ & $\begin{array}{c}31.0 \\
(16.1 ; 48.9)\end{array}$ & $\begin{array}{c}61.0 \\
(34.6 ; 84.5)\end{array}$ & $\begin{array}{c}35.4 \\
(14.7 ; 57.1)\end{array}$ & $\begin{array}{c}41.1 \\
(22.1 ; 61.2)\end{array}$ \\
\hline $\begin{array}{l}\text { Ratio } \\
(95 \% \text { Cl) }\end{array}$ & $\begin{array}{c}1.5 \\
(1.1 ; 2.2)^{*}\end{array}$ & $\begin{array}{c}0.5 \\
(0.1 ; 1.4)\end{array}$ & $\begin{array}{c}0.6 \\
(0.2 ; 1.2)\end{array}$ & $\begin{array}{c}1.2 \\
(0.2 ; 2.9)\end{array}$ & $\begin{array}{c}0.9 \\
(0.2 ; 1.9)\end{array}$ \\
\hline \multicolumn{6}{|c|}{$\%$ reporting the sensation that the medicine has contributed to the reduction of craving } \\
\hline $\begin{array}{l}\text { Homeopathy - mean } \\
(95 \% \mathrm{CI})\end{array}$ & - & $\begin{array}{c}24.5 \\
(5.0 ; 51.9)\end{array}$ & $\begin{array}{c}65.9 \\
(66.6 ; 89.2)^{*}\end{array}$ & $\begin{array}{c}91.7 \\
(64.0 ; 99.9)^{*}\end{array}$ & $\begin{array}{c}67.4 \\
(33.3 ; 93.0)^{*}\end{array}$ \\
\hline $\begin{array}{l}\text { Placebo - mean } \\
(95 \% \mathrm{CI})\end{array}$ & - & $\begin{array}{c}55.0 \\
(2.7 ; 81.2)\end{array}$ & $\begin{array}{c}68.9 \\
(34.5 ; 93.3)\end{array}$ & $\begin{array}{c}72.3 \\
(41.0 ; 94.1)\end{array}$ & $\begin{array}{c}74.3 \\
(45.0 ; 95.0)\end{array}$ \\
\hline $\begin{array}{l}\text { Ratio } \\
\text { (95\% Cl) }\end{array}$ & - & $\begin{array}{c}0.4 \\
(0.1 ; 1.2)\end{array}$ & $\begin{array}{c}1.0 \\
(0.5 ; 2.0)\end{array}$ & $\begin{array}{c}1.3 \\
(0.8 ; 2.3)\end{array}$ & $\begin{array}{c}0.9 \\
(0.4 ; 1.7)\end{array}$ \\
\hline
\end{tabular}

* Statistically different from basal week. 


\section{References}

1. Farmacopéia Homeopática Brasileira. $2^{a}$ ed. São Paulo: Editora Atheneu, 1997.

2. Halikas JA, Kuhn KL, Crosby R, Carlson G, Crea F. The measurement of craving in cocaine patients using the Minnesota Cocaine Craving Scale. Compr Psychiatry. 1991;32:22-7.
3. Lingjaerd $\mathrm{O}$. The UKU side effects rating scale: scale for registration of unwanted effects of psychotropics. Acta Psychiat Scand. 1976;334:81-94. 